\title{
UMA MISSANGA: UMA MULHER - UMA PERSPETIVA LITERÁRIO-JURÍDICA
}

\author{
A BEAD: A WOMAN - A LEGAL-LITERARY PERSPECTIVE
}

Marlene Mendes*

RESUMO: Os contos "As três irmãs", "O cesto", "A saia amarrotada", "Meia culpa, meia própria culpa", "Na tal noite" e "Os olhos dos mortos" que compõem o Fio das Missangas, da autoria de MIA COUTO, contos que descrevem o viver, o sentir, o "ser" de várias personagens - sempre mulheres constituem a base sobre a qual, de uma perspetiva literário-jurídica, se abordam alguns dos direitos fundamentais baseados na dignidade do Ser Humano consagrados, in casu e em particular, na Constituição da República Portuguesa. As vivências das várias mulheres nos referidos contos de MIA COUTO são equacionados à luz dos direitos à identidade, à imagem e à intimidade, à formação e ao desenvolvimento da personalidade, à garantia constitucional da dignidade pessoal e da identidade genética do ser humano, à igualdade dos cônjuges, inseridos num âmbito mais amplo que abrange, entre outros, o direito à vida e o direito à igualdade - na sua vertente de igualdade de género. Desse modo, o presente trabalho é composto, essencialmente, por duas partes: uma primeira parte intitulada uma missanga: uma mulher - centrada na apresentação da perspetiva literária e uma segunda parte intitulada - a mulher no Direito - em que à primeira perspetiva se adita a perspetiva jurídica.

PALAVRAS-CHAVE: Direito. Literatura. Mia Couto. Mulher. Igualdade de género. Direitos fundamentais. Direitos de personalidade.

ABSTRACT: Based in " The three sisters", "The basket", "The skirt crumpled", "Half guilt, half own fault", "In such a night" and "The eyes of the dead", some of the tales that compose the literary work The threat of beads of MIA COUTO, tales that describe the life, the feelings and the "to be" of various characters - all woman - are the base for study the fundamental Human Rights which base is the Human Dignity and that we can perform, in these concrete study, in the Portuguese Constitution. The perspective of this study is a literary-juridical perspective. The life and feelings of the woman's described in the tales are studied in face of the various legal and fundamental rights like the right to an identity, the right to image and to private life, the right to training and development of the personality, the constitutional warranty to the personal dignity and to the genetic identity, the right to the equality between man and wife. The present study as, essentially, two parts: the subject of the first one - a woman: a bead- related to the literary perspective and the second one - the woman on the law - related with the legal perspective.

KEYWORDS: Law. Literature. Mia Couto. Woman. Gender equality. Fundamental rights. Personality rights.

* Mestre em Direito Universidade Nova de Lisboa. Docente do Ensino Superior Politécnico, Lisboa, Portugal. Email: marlenemendes@gmail.com 


\section{INTRODUÇÃO}

O título que escolhemos para o presente trabalho: Uma missanga: uma mulher uma perspetiva literário-jurídica pretende espelhar, em poucas palavras, a base em que assenta a nossa reflexão. O Fio das Missangas de Mia Couto constitui a fonte a partir da qual pretendemos refletir o direito.

A obra apresenta-nos um conjunto de contos: "estórias breves mas contendo, cada uma delas, as infinitas vidas que se condensam em cada ser humano". São "contos unidos como missangas em redor de um fio" (MIA COUTO, 2004).

O Fio das Missangas é descrito, nas palavras do próprio autor, da seguinte forma:

"A missanga, todas as vêem.

Ninguém nota o fio que,

Em colar vistoso, vai compondo as missangas.

Também assim é a voz do poeta:

Um fio de silêncio costurando o tempo."

Ora as missangas, ou seja as "estórias" reunidas nesta obra, trazem à literatura o sentir de várias personagens, quase sempre mulheres, nas mais diversas situações da vida. Situações da vida que nos são descritas como "transpirando" a realidade que ainda hoje se vive em muitos locais da Terra, ou porventura, ainda em todo o planeta: a diferença entre homens e mulheres, a diferença de género entre a "espécie humana".

As diferenças de gênero, facilmente constatadas pelas efetivas diferenças biológicas entre o ser masculino e o feminino e graças às quais se perpetua a espécie humana, sempre foram um produtivo campo de investigação para as diversas áreas do saber.

No âmbito dessa investigação, se inicialmente era uma evidência, mesmo para as ciências sociais e para autores como DURKHEIM ou FREUD, que eram as diferenças biológicas entre os sexos que implicavam as diferenças psicológicas, investigadores mais recentes, na sequência das mudanças que têm vindo a ocorrer no último século, consideram as diferenças entre géneros como factos sociais, pois já não é, tanto, a natureza dos seres que define as suas características psicológicas, mas sim a natureza do tecido das relações em que as pessoas participam, numa perspetiva mais relacional, que modela a maneira como elas se comportam em relação aos outros e a maneira como elas se representam reciprocamente e como constroem a sua identidade (AMÂNCIO, 1994, p. 9).

Essa questão da diferença de géneros, sempre patente ao longo da história da humanidade, é dotada de uma grande virtude - mantém atualidade permanente. Já muito se escreveu, já muito se pensou e refletiu, já muito se legislou mas muito mais há a escrever, pensar, refletir e legislar.

Não esqueçamos que estamos perante uma questão que, desde tempos remotos, se encontra envolta em um certo misticismo como é patente em Pitágoras: "há um princípio bom que criou a ordem, a luz e o homem, e um princípio mau que criou o caos, as trevas e a mulher". 
Neste trabalho não pretendemos nos debruçar sobre a pertinência da linguagem, instrumento por excelência quer do Direito quer da Literatura ("o mundo do Direito, como esfera de exercícios de linguagem especificamente vocacionada; e o mundo da criação e vivência literária, como espaço de liberdade (tradicionalmente assim visto) de aplicação e criação de linguagem" (FREITAS, 2002, p. 7), assumindo que "tanto na interpretação jurídica como na interpretação de textos literários nos vemos confrontados com elementos ligados à linguagem e ao apuramento do sentido e alcance das suas construções. Em ambas as esferas estamos em face de textos que reclamam clarificação e esclarecimento, que reclamam reflexão, assim como estamos face a sujeitos, destinatários dos textos, a quem compete perscrutar, para deles retirar sentido e 'utilidade', o seu alcance como objeto de análise" (FREITAS, 2002, p. 17).

Porque "o que verdadeiramente deverá interessar ao cultor dos estudos jusliterários é a riqueza humana da obra literária, ou seja, são os retratos psicológicos, éticos e sociais que a mesma obra trace de personagens, de situações e de acontecimentos, que poderão ou não estar, cada um deles, diretamente comprometidos com a esfera jurídica. Porque a matéria-prima do Direito é a própria vida, são as relações humanas, sociais e profissionais que os sujeitos vão estabelecendo uns com os outros. A compreensão mais profunda da natureza humana, o conhecimento dos possíveis, prováveis ou improváveis comportamentos do homem ou da mulher perante circunstâncias tão diversas como aquelas com que a vida constantemente nos desafia, são potenciados pela exposição aos textos literários" (SILVA, 2008, p. 57), tendo igualmente consciência de que "as nossas escolhas refletem aquilo que somos. Refletem o que sabemos, o que sentimos, o que pensamos. Os nossos receios, as nossas convicções, as nossas preferências" (SILVA, 2008, p. 61). Este fato é fundamento de muitas críticas dirigidas aos estudos jusliterários, criticando-se "o uso tendencioso e ideologicamente orientado da literatura por parte dos juristas, que fazem a seleção das obras literárias a analisar em função dos argumentos que visam defender" (SILVA, 2008, p. 61).

No presente trabalho não pretendemos discutir a consagração legislativa da igualdade de gênero como valor fundamental e princípio estruturante da nossa sociedade. Mas uma coisa é o que está formalmente consagrado e outra é o que materialmente existe. E é até frequente que determinadas ideias erradas, por estarem enraizadas numa sociedade ou numa cultura, acabem por assumir a aparência de verdades consentidas e inconscientemente aceites (SILVA, 2008, p. 68). A esse respeito, a leitura permite "o contacto com estas narrativas" e "pode contribuir para uma lenta e gradual mudança das mentalidades" (SILVA, 2008, p.68), fato pelo qual o estudo interdisciplinar dos aspetos formais e materiais é relevante.

Nesse âmbito, esta nossa reflexão entre a realidade descrita no Fio das Missangas de Mia Couto e alguns dos princípios base do Direito vigente, podem em nosso entender, e sem margem para dúvida, contribuir para a melhoria do Direito positivado, assim 
reforçando o seu carácter de ciência social. Além disso, porque muitas vezes "a vida que vivemos, o universo em que nos movemos, são com frequência demasiado estreitos e paroquiais para que consigamos sentir a riqueza de todas as vidas possíveis. A literatura possibilita-nos um acesso, indireto, mediato e certamente fragmentado, a muita dessa vida que de outra forma não cabe na nossa" (SILVA, 2008, p. 58) e que também não cabe na vida ou no conceito de vida e de sociedade de quem tem o poder de legislar.

Que este estudo possa servir para fazer o seu leitor refletir e olhar "à sua volta" e verificar se ainda existem, em pleno século XXI, situações idênticas às descritas por Mia Couto nestes contos e, se tal acontecer, que contribua com o valor do seu "eu" para a alteração desse status quo, porque no processo de mudança de mentalidades, cada um de nós é protagonista!

\section{UMA MISSANGA: UMA MULHER}

\section{A MULHER NOS CONTOS DO FIO DAS MISSANGAS}

Ao percorrer o Fio das Missangas de Mia Couto é patente a questão dos gêneros, as representações do feminino e do masculino.

Através de várias das "estórias" reunidas nesta obra, Mia couto traz-nos à literatura o sentir de várias personagens, mulheres, em diversas situações da vida. Os contos "As três irmãs", "O cesto", "A saia amarrotada", "Meia culpa, meia própria culpa", "Na tal noite" e "Os olhos dos mortos" retratam vidas de mulheres que vivem "presas" a uma figura masculina. Assim, num primeiro momento iremos descrever sucintamente os contos supraidentificados, para posteriormente procedermos a uma análise conjunta dos mesmos.

\section{1) "As três irmãs":}

Neste conto descreve-se a vida e o sentir de três irmãs que, depois da morte de sua mãe, são por seu pai "transformadas". É o pai que lhes traça o destino, de tal modo que as próprias mulheres (moças) nem se atrevem a sentir sensações diversas, afastandoas, apagando-as, ou seja, omitem a sua vida, não têm vida própria.

Gilda, Flornela e Evelina, filhas do viúvo Rosaldo, veem o seu destino ser traçado pelo pai: "O destino que Rosaldo semeara nelas: o serem filhas exclusivas e definitivas. Assim postas e não expostas, as meninas dele seriam sempre e para sempre. Suas três filhas, cada uma feita para um socorro: saudade, frio e fome".

As três moças são educadas e vivem em função de seu pai e com vista a prover as necessidades deste: a saudade de sua falecida esposa, o sentir frio e o sentir fome. Elas silenciam e adiam o seu ser, como refere o autor quando diz "espreitemos o seu silencioso e adiado ser": 
Gilda a mais velha, é a rimeira, "sabia rimar", pelo que o pai destinou que "a moça seria poetisa", mas "mais ela versejava, menos a vida nela versava" e Gilda, de acordo com a vontade de seu pai, sempre omitia sua vontade, oprimia o seu ser "de quando em quando, uma brisa desarrumava os arbustos. E o coração de Gilda se despenteava. Mas logo ela se compunha e, de novo, caligrafava". O estado de espírito desta mulher é-nos demonstrado pelo bater acelerado de seu coração, que esta logo cala, o adiar da sua vontade e do seu ser está patente na descrição "ao contrário, cumpria a função de afastar a poesia, essa que morava onde havia coração", motivo pelo qual "a rima não gerava poema" e, sem notar, "Gilda estava cometendo suicídio".

Flornela, a do meio, a receitista "se gastava em culinárias ocupações". Vivia na cozinha e para os cozinhados; "no escuro húmido da cozinha, ela copiava as velhas receitas, uma a uma. Redigia palavra por palavra, devagar, como quem põe flores em caixão", assim vivia "lenta", de "mãos suadas" e "acertava panelas e fogo". A sua vontade de viver chamava-a por vezes: "seus seios se agitavam, seus olhos taquicardíacos traindo acometimentos de sonhos", "o esboço de um cantar lhe surgia", mas desde logo, resultado da educação e do destino que o pai lhe traçara, esta silencia o seu ser, "ela apagava a voz como quem baixa o fogo, embargando a labaredazinha que, sob o tacho, se insinuava".

Evelina, a mais nova, a bordadeira, que de tanto bordar se questionava se os seus olhos tinham clareado ou se já eram claros de nascença; "ela em seu ponto não tinha fim". Tal como as irmãs tem a sua vida suspensa e adiada: "certa vez, ela se riu e foi tão tardio, que se corrigiu como se alma estrangeira à boca lhe tivesse aflorado", e a sua mágoa é descrita como o modo como ela pica o dedo com a agulha e no que representa o sangue no dedo "aquele sangue, fora do corpo, era seu desvairo, o convocar da amorosa mácula" e, tendo consciência do seu estado, "Evelina chorava a sua própria morte".

$\mathrm{O}$ aparecimento de um jovem representa a hipótese que estas três irmãs têm de "tomar as rédeas da vida", mas mais uma vez o pai decide "cortar o mal e a raiz" e depois de uma tentativa frustrada de matar o jovem, acaba por beijá-lo. Ou seja, mais uma vez o pai retira àquelas jovens a possibilidade de viverem e terem vontade própria, ao ficar ele com aquele (o jovem) que representava a esperança de viver das três irmãs.

\section{2) "O cesto":}

Neste conto retrata-se a vida de uma mulher que nunca foi amada pelo marido: "ele nunca me escutou", ele somente "devorava os meus preparados. A comida era onde eu não me via recusada". Mais uma vez, estamos perante esta mulher que agora vive num profundo silêncio e cujo único objectivo de vida é preparar o cesto para levar alguma comida ao marido moribundo que se encontra internado no hospital: "hoje será como todos os dias: lhe falarei, junto ao leito, mas ele não me escutará. Não será essa a diferença. Ele nunca me escutou. Diferença está na marmita que adormecerá, sem 
préstimo, na sua cabeceira. Antes, ele devorava os meus preparados". Ciente da sua situação atual, esta mulher reconhece para si mesma que o silêncio atual não é mau “agora, pelo menos, já não sou mais corrigida. Já não recebo enxovalho, ordem de calar, de abafar o riso". A história de vida de uma mulher que sempre foi maltratada pelo marido "- você, marido, enquanto vivo me impediu de viver", reconhecendo que "onde eu vivo não é na sombra. É por detrás do sol, onde toda a luz há muito se pôs"; "a meu homem deram transfusão de sangue. Para mim, o que eu queria era transfusão de vida, o riso me entrando na veia até me engolir, cobra de sangue me conduzindo à loucura". Por tudo isso, esta mulher deseja a morte do marido: "a sua vida me apagou. A sua morte me fará nascer. Oxalá você morra, sim, e quanto antes", o que efetivamente vem a acontecer. No entanto, com a morte do marido esta mulher em vez de renascer, vê que não consegue mudar de vida, de tal modo se encontra moldada pela sua anterior vida: "saio do hospital à espera de ser tomada por essa nova mulher que em mim se anunciava. Ao contrário de um alívio, porém, me acontece o desabar do relâmpago sem chão onde tombar".

\section{3) "A saia amarrotada":}

Neste conto retrata-se a vida e o sentir de uma jovem que, nas suas palavras, nasceu para "cozinha, pano e pranto". Imbuída deste espírito, e ao contrário do que se passava com as restantes mulheres da sua vila ("a única vila do mundo") que sonhavam com vestidos novos para saírem, quando lhe deram a ela uma saia de rodar trancou-se em casa: "ensinaram-me tanta vergonha em sentir prazer, que acabei sentindo prazer em ter vergonha". Porque "belezas eram para as mulheres de fora. Elas desencobriam as pernas para maravilhações. Eu tinha joelhos era para descansar as mãos".

Esta jovem "estava tão habituada a não ter motivo" que ao ser-lhe oferecida a saia se enrolou no velho sofá. Esta jovem, que era a "única menina entre a filharada", foi "cuidada por meu pai e meu tio. Eles me quiseram casta e guardada. Para tratar deles, segundo a inclinação das suas idades". Ciente do meio em que vivia, a jovem "mais que o dia seguinte" "esperava pela vida seguinte". Esta moça, que não chegou a conhecer a mãe, cujo óbito ocorre com o parto, vê toda a sua vida marcada por esse acontecimento "desde nascença, o pudor adiou o amor" e "uma tristeza de nascença me separava do tempo. As outras moças, das vizinhanças, comiam para não ter fome. Eu comi a própria fome". A sua vida é retratada pelo modo como vai para a mesa à hora da refeição, sentando-se numa "estreiteza entre cotovelos em redor da mesa", mesa e refeição essa em que "os braços se atropelavam, disputando as magras migalhas. Em casa de pobre ser o último é ser nenhum. Assim eu não me servia". O seu estado de espírito é retratado "meu coração já me tinha expulso de mim. Estava desalojada das vontades" e sentia o facto de o pai ou o tio não a tratarem pelo nome "- Deixem um pouco para a miúda. (...) Um pouco para a miúda: assim, sem necessidade de nome. 
Que o meu nome tinha tombado nesse poço escuro em que minha mãe se afundara". A passagem desta jovem pela vida é comparada à fome "atravessando vagarosamente a fome", porque "não tenho nome, faltava só não ter corpo", assim a jovem atravessa vagarosamente a vida e "só a lágrima me desnudava, só ela me enfeitava". A esperança de uma vida melhor é retratada através da esperança de vinda de um homem "na lágrima flutuava a carícia desse homem que viria. Esse aprincesado me iria surpreender. E me iria amar em plena tristeza. Esse homem me daria, por fim, um nome. Para o meu apetite de nascer, tudo seria pouco, nesse momento".

Toda a existência desta jovem é moldada por seu pai, que esta continua a ouvir mesmo depois de morto: "chega-me ainda a voz de meu velho pai como se ele estivesse vivo. Era essa voz que fazia Deus existir. Que me ordenava que ficasse feia, desviçosa a vida inteira", "sempre ceguei em obediência, enxotando tentações que piripirilampejavam a minha meninice. Obedeci mesmo quando ele ordenou: - Vá lá fora e pegue fogo nesse vestido!". Esta ordem para queimar o vestido, é mais uma ordem para que esta "esqueça sua vida", pelo que em vez de obedecer ao pai e queimar a saia, "lancei, sim, fogo sobre mim mesma" e esse ato para ela "não eram chamas. Eram as mãos escaldantes do homem que veio tarde".

Toda a existência desta rapariga é apagada/oprimida pelo pai "é essa voz que ainda paira, ordenando a minha vez de existir. Ou de comer. E escuto a sua ordem para que a vida me ceda a vez", "agora, estou sentada, olhando a saia rodada, a saia amorfanhosa, almarrotada. E parece que me sento sobre a minha própria vida".

4) "Meia culpa, meia própria culpa":

Aqui se conta a história de Maria Metade, nome justificado em virtude de esta mulher se considerar incompleta "nunca quis. Nem muito, nem parte. Nunca fui eu, nem dona, nem senhora. Sempre fiquei entre o meio e a metade. Nunca passei de meios caminhos, meios desejos, meia saudade". Maria Metade, cujo marido, tendo várias amantes, para ela não olhava: "das poucas vezes que me falou, nunca para mim olhou. Estou ainda por sentir seus olhos pousarem em mim". Maria Metade considerava-se "o que eu era: um gasto, um extravio de coisa nenhuma" e sua vida é um nada "(...) desejando ser condenada para o resto deste nada que é a minha vida", admitindo que "a nós, menores de existência, resta-nos a mentira", como se toda sua vida fosse uma mentira; “(...) eu minto até a Deus. Sim, Lhe minto a Ele. Afinal, Deus me trata como meu marido: um nunca me olha, o Outro nunca me vê".

Ao longo da narrativa, a personagem, acusada de ter assassinado o marido, declara: "aqui, penumbreada nesta prisão, não sofro tanto quanto sofria antes. É que aqui, sabe, acabo saindo mais que lá em minha casa natal. Vou onde? Saio pelo pé de meu pensamento", "depois de matar o Seis reganhei acesso a minhas lembranças", "não entrava no cinema que me estava interdito. Eu tinha a raça errada, a idade errada, a 
vida errada", "não sonhava ser feliz, que isso era demasiado para mim. Sonhava para me sentir longínqua, distante até do meu cheiro". Percebe-se do decorrer do conto que afinal esta mulher não era culpada pela morte do marido (não obstante ela ter pensado em tirar-lhe a vida); este encontrando-se embriagado tinha caído sobre o punhal que ela tinha em suas mãos: "mas não confesso crime, senhor. Não. Afinal, não fui eu que lhe tirei vida. A vida, a bem dizer, já não estava nele", "não o matei. E disso tenho pena. Porque esse assassinato me faria sentir inteira. Por agora, prossigo metade, meia culpada, meio desculpada". E conclui pedindo ao juiz que a condene e declarando que "por maior que seja a pena, não haverá castigo maior que a vida que já cumpri”.

\section{5) "Na tal noite":}

Neste conto retrata-se a vida de uma mulher que vive para seus filhos, no seio da casa. Casada com um marido ausente, "Mariazinha, à porta, espera a anual visita de Sidónio Vidas, o episódico esposo. Ei-lo agora, em aparatosa aparição, santificado seja ele e mais a sua vaidosa viatura. Ele nunca tanto chegara. Fazia como a chuva procede com as fontes secas: inundava após ausência", trabalhador no estrangeiro "(...) o pai trabalhava longe em país muitíssimo estrangeiro" e "com vida dupla" - "- Mas você pode trazer os seus outros....os irmãos dos seus filhos. E pode trazer a... ela, também. Eu não me importo, Sidónio" ou seja com uma outra família. Nesta história, retrata-se um casamento "(...) a noite sem núpcias, o esposo cadente, com juramento sem prazo de viabilidade". $\mathrm{O}$ marido chega a casa "a esposa segue-o, diminuta, protocolar", "o marido senta-se à mesa, refastelado, dono. Vai desapertando a fivela do cinto para, em prevenção, se valer por dois", "a esposa comendo em pé, prato no apoio da mão, vai olhando o marido". O sofrer, a opressão desta mulher é-nos demonstrada "Mariazinha recolhe o prato, junto com a lágrima". A noite em que são narrados os acontecimentos - noite de Natal - é marcante, pois nessa noite "Sidónio, pela primeira vez, concede olhar a esposa".

6) "Os olhos dos mortos":

Neste conto, a mulher é vítima de agressões físicas pelo marido. A história começa por nos contar as expetativas desta mulher, o seu anseio "hoje não, eu me desmesuro, pronta a criancices e desatinos". Ciente, no entanto, do "lugar" da mulher reconhece que "minha alegria, assim tanta, só pode ser errada", "e eu, durante anos, tive vergonha da alegria. Estar-se contente, ainda vá. Que isso é passageiro. Mas serse alegre é excessivo como pecado mortalício". Mas estes anseios são contrários à dura realidade "durante anos, porém, os passos de meu marido ecoaram como a mais sombria ameaça. (...) Cumpria o fel de seu querer: me vergastava com socos e chutos. No final, quem chorava era ele para que eu sentisse pena de suas mágoas. Eu era culpada de suas culpas", depois “com o tempo, já não me custavam as dores”, "Venâncio estava na violência como quem não sai do seu idioma. Eu estava no pranto 
como quem sustenta sua própria raiz. Chorando sem direito a soluço; rindo sem acesso a gargalhada. O cão se habitua a comer sobras. Como eu me habituei a restos de vida". A imagem desta mulher é-nos ainda demonstrada por meio da descrição que faz de um retrato: "nele figurava Venâncio, ainda magro e moço, posando na nossa varanda. Pelo olhar se via que sempre fora dono e patrão. Surjo atrás, desfocada, esquecida. Sem pertença nem presença".

A esperança para esta mulher é representada por uma gravidez que julga ter mas que não era real "desmaiada, me espreitaram os dentros: gravidez não havia. Mais uma vez era falsa esperança. Esse vazio de mim, essa poeira de fonte seca, o não poder dar descendência a Venâncio, isso doía mais que perder um filho. Eu estava mais estilhaçada que o retrato da sala (...), quando me despertei, me acreditei já morta, transferida para outro mundo. Morrer não me bastava: nesse depois ainda Venâncio me castigaria. Eu necessitava um outro jamais. Adivinhei as minhas fúnebres cerimónias (...)".

O temor da mulher é incrementado pelo fato de, desta vez, ter recorrido ao hospital, quando "até ali eu fechara as minhas feridas no escuro íntimo do lar. Que é onde a mulher deve cicatrizar". Com receio de novas agressões, ao chegar a casa esta mulher acaba por matar o marido recorrendo a um dos estilhaços de vidro do retrato ainda espalhados pelo chão da sala. Trata-se da "cruel dança do tempo. Nessa dança, quem bate o tambor é a mão da morte".

Assistimos nestes contos ao descrever de histórias de vida. Histórias estas, na sua maioria narradas no feminino, ou seja, contadas pelas próprias mulheres personagens nos contos onde descrevem a sua vida, ou melhor, o seu "inexistir", o modo como o sentem e a esperança que têm em mudar de vida, quanto mais não seja, mediante a "obtenção" de uma nova vida. Essa esperança é descrita ao longo destes contos, quer com recurso analógico a devaneios amorosos, ao despertar e viver de um amor com um homem ou até mesmo a uma gravidez. No entanto, em quase todos os contos descritos é patente que a figura feminina ocupa as margens, sempre na dependência ou na sombra da figura masculina. A sua opressão dá origem a um movimento de busca pela liberdade, numa história repleta de dores, cicatrizes e tentativas de silenciamento (ALVES, 2009). Aqui, a comunidade em que se insere a mulher, os valores educacionais e culturais que lhe são transmitidos provocam na mulher "vergonha de sentir", a ponto de estas reprimirem o seu próprio viver, se silenciarem e viverem em função de outro, seja esse outro o seu marido ou o seu pai, mas em regra, uma figura masculina.

Essas narrativas são descritas muitas vezes por mulheres inominadas. Verifica-se que, ao contrário das personagens masculinas a quem é atribuído um nome, o mesmo não acontece às personagens femininas, descritas genericamente, sem personalização atribuída através de um nome, ou seja, descrita como figura comum, como ser que sendo "secundário", vive na sombra, em função de outrem e a quem incumbe desempenhar determinado papel social sempre aferido em função e em prol desse mesmo outro. 
O seu mundo é o mundo das quatro paredes da casa, aí se dedicando aos afazeres domésticos, cozinhar, limpar, tricotar, gerar filhos e deles cuidar. Personagens femininas sem autonomia, sem independência, sem personalidade, sem vida... até porque as mesmas silenciam essa vontade de viver, por receio, por respeito a seu marido ou pai, por imposição moral ou educacional.

Em todas essas histórias, é narrada a trajetória de opressão de uma mulher e os mecanismos por ela utilizados na sua tentativa de libertação. Assim, maioritariamente narrados na primeira pessoa, os textos atuam como um testemunho da condição feminina, marginal e discriminada ou assinalando a exclusão da personagem em relação ao seu grupo social (ALVES, 2009).

No início dos contos são descritos os sonhos das mulheres ou são-nos dadas informações que nos situam perante a situação vivenciada pela protagonista ou é-nos fornecido o "tempo interno da personagem, no mesmo espaço da morada (o quarto, a casa)" (QUELHAS, 2001), personagem essa que parece à margem da sociedade em que vive, por exemplo:

- no conto "As três irmãs": "o destino que Rosaldo semeara nelas: o serem filhas exclusivas e definitivas. Assim postas e não expostas, as meninas dele seriam sempre e para sempre. Suas três filhas, cada uma feita para um socorro: saudade, frio e fome";

- no conto "O cesto": "ele nunca me escutou"; "ele devorava os meus preparados. A comida era onde eu não me via recusada";

- no conto "Saia amarrotada": "A mim, quando me deram a saia de rodar, eu me tranquei em casa. Mais que fechada, me apurei invisível, eternamente nocturna. Nasci para cozinha, pano e pranto. Ensinaram-me tanta vergonha em sentir prazer, que acabei sentindo prazer em ter vergonha";

- no conto "Meia culpa, meia própria culpa": “(...) nunca fui eu, nem dona, nem senhora. Sempre fiquei entre o meio e a metade. Nunca passei de meios caminhos, meios desejos, meia saudade";

- no conto "Na tal noite": "vinte e cinco, Natal. (...) Mariazinha, à porta, espera a anual visita de Sidónio Vidas, o episódico esposo. Ei-lo agora, em aparatosa aparição, santificado seja ele e mais a sua vaidosa viatura. Ele nunca tanto chegara. Fazia como a chuva procede com as fontes secas: inundava após ausência"; "(...) a noite sem núpcias, o esposo cadente, com juramento sem prazo de viabilidade";

- no conto "Os olhos dos mortos": "hoje não, eu me desmesuro, pronta a criancices e desatinos"; "durante anos, porém, os passos de meu marido ecoaram como a mais sombria ameaça. (...) Cumpria o fel de seu querer: me vergastava com socos e chutos". 
E se, aparentemente, das primeiras palavras descritas nos contos parece existir a sugestão de uma clausura quase voluntária, note-se que a atitude das personagens é decorrente de uma educação em que as noções de prazer e vergonha se (con)fundem, em que a atitude das personagens é moldada por valores e noção de cumprimento de deveres que lhes são transmitidos. No entanto, cientes de que não há saída possível, os discursos são amargos e cépticos, apresentando-nos alguém que, mais do que o dia seguinte, espera pela vida seguinte, na constatação desencantada de que a única opção é nascer de novo. Nos textos narrados denuncia-se esta percepção amarga e abandonada, acerca da própria condição:

- “(...) eles me quiseram casta e guardada. Para tratar deles, segundo a inclinação das suas idades"; "Uma tristeza de nascença me separava do tempo. As outras moças, das vizinhanças, comiam para ter fome. Eu comi a própria fome. (...) Meu coração já me tinha expulso de mim. Estava desalojada das vontades", em "A saia amarrotada";

- "mas ela apagava a voz como quem baixa o fogo, embargando a labaredazinha que, sob o tacho se insinuava", em "As três irmãs";

- “onde vivo não é na sombra. É por detrás do sol, onde toda a luz há muito se pôs”, em "O cesto";

- "não entrava no cinema que me estava interdito. Eu tinha a raça errada, a idade errada, a vida errada", em "Meia culpa, meia própria culpa";

- "O cão se habitua a comer sobras. Como eu me habituei a restos de vida", em "Os olhos dos mortos".

À medida que se avança nas histórias, percebemos toda a realidade circundante que acabou por acarretar a quase clausura em que vivem, num aniquilamento social, a partir de atitudes e situações que as desqualificam como sujeito da sua própria vida. As protagonistas parecem ter uma existência que se justifica somente pela função de cuidar dos outros:

- "Suas três filhas, cada uma feita para um socorro: saudade, frio e fome", em "As três irmãs";

- “hoje será como todos os dias: lhe falarei, junto ao leito, mas ele não me escutará. Não será essa a diferença. Ele nunca me escutou. Diferença está na marmita que adormecerá, sem préstimo, na sua cabeceira. Antes, ele devorava os meus preparados", em "O cesto";

- "Nasci para cozinha, pano e pranto"; "Para tratar deles segundo a inclinação das suas idades", em "A saia amarrotada".

A ausência de um nome (verificada em alguns dos contos em análise) que lhe confira individualidade ou singularidade parece acentuar essa sensação de inexistência: "Um pouco para a miúda: assim, sem necessidade de nome. Que o meu nome tinha tombado nesse poço escuro em que minha mãe se afundara", narrações em que, embora sejam as mulheres as narradoras, em momento algum há uma referência ao seu nome. Ora, este fato de não serem dotadas de um nome - ainda que o tenha, nem a própria personagem faz menção a ele, em momento algum - acaba por intensificar a sensação de não pertença à sociedade vivenciada pela protagonista (ALVES, 2009). 
Por outro lado, as tentativas de libertação das personagens aparecem-nos sob diferentes aspetos:

i) figuras masculinas:

"Na lágrima flutuava a carícia desse homem que viria. Esse aprincesado me iria surpreender. E me iria amar em plena tristeza. Esse homem me daria, por fim, um nome. Para o meu apetite de nascer, tudo seria pouco, nesse momento", em "Saia amarrotada";

"Mas eis: uma súbita vez, passou por ali um formoso jovem. E foi como se a terra tivesse batido à porta de suas vidas. Tremeu a agulha de Evelina, queimou-se o guisado de Flornela, desrimou-se o coração de Gilda", em "As três irmãs";

"não eram chamas. Eram as mãos escaldantes do homem que veio tarde", em "A saia amarrotada";

ii) renascer dando vida, por meio de uma gravidez:

“desmaiada, me espreitaram os dentros: gravidez não havia. Mais uma vez era falsa esperança", em "Os olhos dos mortos".

iii) ou ainda, mediante quer da provocação de dor em si própria, do desejo ou do recurso à morte, quer desejando ou provocando a morte daqueles que "as impedem de viver". Para estas mulheres, a morte afigura-se como algo positivo, em virtude da infelicidade em que vivem. Expressões como dançava entre labaredas ou acarinhada pela quentura do enfim mostram uma cena de tentativa de suicídio revestida de elementos quase poéticos, numa sugestão de que a morte traria à personagem a beleza e o lirismo jamais concedidos em vida. Ao longo dos contos são inúmeros os exemplos que podemos recolher de como a morte é acolhida e desejada:

- "aquele sangue, fora do corpo, era seu desvairo, o convocar da amorosa mácula", em "As três irmãs";

- "a sua vida me apagou. A sua morte me fará nascer", em "O cesto";

- "lancei, sim, fogo sobre mim mesma. (...) já eu dançava entre labaredas, acarinhada pelas quenturas do enfim", em "A saia amarrotada";

- "Por isso lhe peço, doutor escritor. Me ajude numa mentira que me dê autoria da culpa. Uma inteira culpa, uma inteira razão de ser condenada. Por maior que seja a pena, não haverá castigo maior que a vida que já cumpri”, em "Meia culpa, meia própria culpa”;

- "Eu chamo a cruel dança do tempo. Nessa dança, quem bate o tambor é a mão da morte.

(...) E é o que faço ao meu marido. Lhe fecho os olhos, agora que o seu sangue se espalha, avermelhando os lençóis", em "Os olhos dos mortos". 
Essas "condições de salvação" ou de "renascimento" das personagens femininas dos contos mostram como a identidade da mulher está condicionada à existência de um homem e que sempre que o aparecimento do "príncipe" não fosse a solução, essa solução consistia no recurso à morte, assim se demonstrando a incapacidade da mulher de se opor ao homem, a sua frágil condição quer em termos sociais, quer em termos econômicos, não podendo, em muitos dos casos, prover ao seu próprio sustento.

As histórias vão sendo relatadas e vai-se transmitindo ao leitor a perceção do decurso do tempo e o modo como uma juventude não vivida se transforma numa velhice em que já não é possível voltar atrás e viver o que não se viveu, mesmo nas situações em que o "elemento constrangedor", o pai ou o marido, já não existem. As suas vidas continuam vazias, assim demonstrando que, mais que uma imposição, nas presentes narrações estamos perante verdadeiros estados de alma, como tal sentidos e assimilados, assim se justificando o poder de "aniquilar" vidas. Estas mulheres por vezes nem se sentem vivas:

- "Gilda estava cometendo suicídio"; "Evelina chorava a sua própria morte", em "As três irmãs";

- "saio do hospital à espera de ser tomada por essa nova mulher que em mim anunciava. Ao contrário de um alívio, porém, me acontece o desabar do relâmpago sem chão onde tombar", em "O cesto";

- "é essa voz que ainda paira, ordenando a minha vez de existir. Ou de comer. E escuto a sua ordem para que a vida me ceda a vez"; "agora, estou sentada, olhando a saia rodada, a saia amorfanhosa, almarrotada. E parece que me sento sobre a minha própria vida", em "A saia amarrotada";

- "não o matei. E disso tenho pena. Porque esse assassinato me faria sentir inteira", em "Meia culpa, meia própria culpa";

- "morrer não me bastava: nesse depois ainda Venâncio me castigaria. Eu necessitava um outro jamais", em "Os olhos dos mortos".

Em qualquer uma das situações descritas, quando se depara à mulher a possibilidade de ela se libertar, de ser ela própria, de se permitir viver, logo a mesma ou uma outra figura masculina a impedem de obter esse objetivo:

- a jovem que ao incendiar o próprio corpo é salva pelos irmãos, que com esse ato não lhe deixam escolha sobre a própria vida, de tal modo que mesmo depois da morte do pai a jovem mulher ainda aguarda a sua autorização para viver: "É essa voz que ainda paira, ordenando a minha vez de existir. Ou de comer. E escuto a sua ordem para que a vida me ceda a vez. E pergunto: posso agora, meu pai, agora que eu já tenho mais ruga que pregas tem esse vestido, posso agora me embelezar de vaidades? Fico à espera de sua autorização, enquanto vou ao pátio desenterrar o vestido do baile que não houve. E visto-me com ele, me resplandeço ante o espelho, rodopio para enfunar a roupa. Uma diáfana música me embala pelos corredores da casa", em "Saia amarrotada";

- quando o jovem aparece e provoca um terramoto na vida das três irmãs, logo seu pai se opõe pretendendo "cortar o mal e a raiz", "mas eis que o mundo desaba em visão. E os dois homens se beijaram, terna e eternamente. Estrelas e espantos brilharam nos olhos das três irmãs, nas mãos que se apertaram em secreta congeminação de vingança", em "As três irmãs". 
A repressão vivenciada pelas protagonistas ao longo da vida impossibilitou-as de viver, fazendo com que, mesmo agora com o pai ou o marido já mortos, elas ainda aguardem a sua permissão para tal (ALVES, 2009).

Os contos estão repletos de uma linguagem que nos fornece a exata perceção das situações descritas, assim termos como "ordenava" ou "ceguei" são indicativos da não existência da própria identidade ou da sua supressão em virtude da autoridade de outro ou do comportamento do outro. Como se verifica por exemplo, em "A saia amarrotada": "Chega-me ainda a voz de meu velho pai como se ele estivesse vivo. Era essa voz que fazia Deus existir. Que me ordenava que ficasse feia, desviçosa a vida inteira. Eu acreditava que nada era mais antigo que meu pai. Sempre ceguei em obediência, enxotando tentações que piripirilampejavam a minha meninice", sendo inclusive o pai comparado a Deus, e "o mais antigo dos antigos" - "nada era mais antigo que meu pai".

\section{A MULHER NO DIREITO}

No Direito a mulher não poderia deixar de ser "retratada". O direito como ciência social e humana, paradigma de coexistência social (NETO, 2004, p. 21), porquanto centrado na pessoa humana como seu valor programático e determinante (NETO, 2004, p. 192), não poderia deixar de "analisar" a mulher e a questão decorrente do gênero. O próprio direito vale como uma ideia humana (NETO, 2004, p. 192). Assim, a pessoa humana. Toda e qualquer pessoa humana - é o bem supremo da nossa ordem jurídica, o seu fundamento e o seu fim, e este entendido em termos de igualdade e da universalidade (NETO, 2004, p. 196). A dignidade da pessoa humana como objeto de proteção independentemente do gênero - trata-se simplesmente do ser humano.

Como ciência social, é objetivo do Direito regular a vida em sociedade de homens e mulheres. Como ciência social cabe ao Direito o papel de igualar os seres humanos independentemente do seu gênero, pelo que se se verifica existir socialmente uma diferenciação, cabe ao direito tentar eliminá-la. Assim, desde logo a nível do direito internacional, vários instrumentos visam a garantia de igualdade entre homens e mulheres. $\mathrm{Na}$ sequência do reconhecimento pela ONU de doze direitos das mulheres:

- o direito à vida;

- o direito à liberdade e à segurança pessoal;

- direito à liberdade e a estar livre de todas as formas de discriminação;

- direito à liberdade de pensamento;

- direito à informação e à educação;

- direito à privacidade;

- direito à saúde e à proteção desta;

- direito a construir relacionamento conjugal e a planear a sua família;

- direito a decidir ter ou não ter filhos e quando tê-los; 
- direito aos benefícios do progresso científico;

- direito à liberdade de reunião e participação política;

- direito a não ser submetida a torturas e maus-tratos,

- direitos estes que são proclamados em vários instrumentos legislativos, de que constituem exemplo:

a) a Convenção sobre a eliminação de todas as formas de discriminação contra as mulheres, adotada e aberta à assinatura, ratificação e adesão pela resolução n. ${ }^{\circ}$ 34/180 da Assembleia Geral das Nações Unidas, de 18 de Dezembro de 1979, que entrou em vigor na ordem internacional a 3 de Setembro de 1981. Portugal assina a convenção em 24 de Abril de 1980 tendo esta entrado em vigor na ordem jurídica portuguesa em 3 de Setembro de 1981. Por meio da presente convenção reafirma-se a fé nos direitos fundamentais do homem, na dignidade e no valor da pessoa humana e na igualdade de direitos dos homens e das mulheres. No art. $5^{\circ}$ deste instrumento internacional prevê-se que: "Os Estados Partes tomam todas as medidas apropriadas para: a) modificar os esquemas e modelos de comportamento sócio-cultural dos homens e das mulheres com vista a alcançar a eliminação dos preconceitos e das práticas costumeiras, ou de qualquer outro tipo, que se fundem na ideia de inferioridade ou de superioridade de um ou de outro sexo ou de um papel estereotipado dos homens e das mulheres";

b) no mesmo sentido a Declaração sobre a eliminação da discriminação contra a mulher proclamada pela Assembleia Geral na Resolução 2263 (XXII), de 7 de Novembro de 1967 afirma no seu artigo $1^{\circ}$ que: "a discriminação contra a mulher, porque nega ou limita sua igualdade de direitos com o homem, é fundamentalmente injusta e constitui uma ofensa à dignidade humana" pelo que nos termos do art. $2^{o}$ "deverão ser tomadas todas as medidas apropriadas para abolir leis, costumes, regras e práticas existentes que constituam discriminação contra a mulher" e para o efeito "deverão ser tomadas todas as medidas apropriadas para educar a opinião pública e dirigir as aspirações nacionais para a erradicação do preconceito e abolição dos costumes e de todas as outras práticas que estejam baseadas na ideia de inferioridade da mulher", de acordo com o art. $3^{\circ}$. Ainda nos termos do art. $6^{\circ}, \mathrm{n}^{\mathrm{o}} 2$ "deverão ser tomadas todas as medidas necessárias para assegurar o princípio de igualdade de condição do marido e da esposa".

Embora a adoção desses instrumentos internacionais de proteção e de garantia dos direitos do homem na ordem interna só tenha ocorrido depois da entrada em vigor da Constituição de 1976, esses instrumentos foram, no entanto, de 
influência decisiva na elaboração da própria lei fundamental portuguesa (NETO, 2004, p. 180).

A consagração de direitos, liberdades e garantias na senda da consagração do princípio da dignidade humana no artigo $2^{\circ}$ da CRP (Constituição da República Portuguesa), apresenta-nos a pessoa como o fim último do direito - "Personae est definitio: naturae rationabilis individua substantia" (NETO, 2004, p. 183) - "E essa dignidade humana, no quadro do Estado Social de Direito, é já não a dignidade do homem isolado do liberalismo mas sim a dignidade da pessoa humana, a um tempo indivíduo e cidadão, ser livre e situado na sociedade, ela tem uma das suas principais revelações no direito que cada indivíduo deve ter "à realização e desenvolvimento da personalidade em quaisquer direções", o que implica a defesa do indivíduo em relação, não só ao Estado, mas também a terceiros, à sociedade civil. O princípio da dignidade do Homem, encarado na sua atual dimensão, vem pois fundamentar a extensão da eficácia dos direitos fundamentais às relações privadas" (ABRANTES, 1990, p. 27).

E, os Direitos Fundamentais como categoria de posições jurídicas ativas "são talvez a realidade ético-jurídica mais próxima dos cidadãos, bandeira dos processos emancipatórios e das pretensões justificadas de liberdade e igualdade dos indivíduos e dos grupos" (NETO, 2004, p. 113). A teoria dos direitos fundamentais integra os direitos fundamentais como categoria dogmática preocupada com a construção sistemáticoconceitual do direito positivo, tendendo a assinalar uma única dimensão (subjetiva) e apenas uma função (proteção da esfera livre e individual do cidadão), entrecruzando-se a dimensão constitutiva e declarativa dos princípios que, eles mesmos, na sua fundamentalidade principal, exprimem, indicam, denotam ou constituem uma compreensão global da ordem constitucional (CANOTILHO, 1995, p. 353). Estes princípios assentam numa base antropológica comum, numa "tríade mágica" do homem como pessoa, cidadão e trabalhador, e articulam-se em termos de complementariedade, condicionando-se mutuamente" (NETO, 2004, p. 118).

$\mathrm{Na}$ linha do consagrado nos instrumentos internacionais identificados, a CRP no título II prevê os direitos, liberdades e garantias onde se incluem: o direito à vida (art. $24^{\circ}$ ), o direito à integridade pessoal (art. 25\%), o direito à liberdade e à segurança (art. $27^{\circ}$ ), o direito à identidade, ao bom nome à imagem e à intimidade (art. $26^{\circ}$ ), o direito ao desenvolvimento da personalidade (art. $26^{\circ}$ ), o direito à inviolabilidade do domicílio e da correspondência ( $\operatorname{art} 34^{\circ}$ ), a garantia da dignidade pessoal e identidade genética do ser humano (art. $26^{\circ}, \mathrm{n}^{\circ} 3$ ), o direito de igualdade dos cônjuges (art. $36^{\circ}, \mathrm{n}^{\circ} 3$ ), a

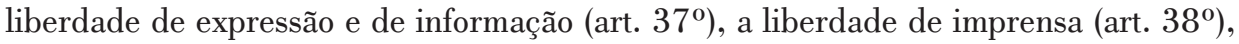
a liberdade de consciência, religião e culto (art. $41^{\circ}$ ), o direito de deslocação e de emigração (art. $44^{\circ}$ ), os direitos de reunião e de associação (art. $45^{\circ}$ e $46^{\circ}$ ). 
Em face das situações mundanas em que se insere a mulher nos contos de Mia Couto, parece-nos ser de reflectir sobre o ser humano como pessoa, como titular de direitos considerados como essenciais no âmbito da vida cotidiana e que o Direito deve reforçar, se necessário por meio do exercício da sua força coercitiva. E quanto aos direitos fundamentais identificados iremos olhar para o direito ao desenvolvimento da personalidade consagrado no art. $26^{\circ}$ da CRP. Efetivamente, o artigo $26^{\circ}$ consagra nove direitos distintos, mas todos eles apresentando de comum o fato de estarem diretamente ao serviço da proteção da esfera nuclear das pessoas e da sua vida (CANOTILHO \& MOREIRA, 2007, p. 461), tratam-se de "outros direitos pessoais", "além da vida e da integridade pessoal, mas integrantes da mesma categoria específica" (CANOTILHO \& MOREIRA, 2007, p. 461).

$\mathrm{O}$ direito ao desenvolvimento da personalidade constitui um direito subjetivo fundamental do indivíduo, garantindo-lhe "um direito à formação livre da personalidade ou liberdade de ação como sujeito autónomo dotado de autodeterminação decisória, e um direito de personalidade fundamentalmente garantidor da sua esfera jurídico-pessoal e, em especial, da integridade desta" (CANOTILHO \& MOREIRA, 2007, p. 463). No seu âmbito normativo de proteção o direito ao desenvolvimento da personalidade apresenta três dimensões (CANOTILHO \& MOREIRA, 2007, p. 463): i) formação livre da personalidade, sem planificação ou imposição estatal de modelos de personalidade; ii) proteção da liberdade de ação de acordo com o projeto de vida e a vocação e capacidades pessoais próprias; iii) proteção da integridade da pessoa para além da proteção do art. $25^{\circ}$ da CRP, tendo sobretudo em vista a garantia da esfera jurídicopessoal no processo de desenvolvimento. Como nos ensinam Gomes Canotilho e Vital Moreira, a primeira e terceira dimensões - proteção da integridade da pessoa, decorriam já do artigo $69^{\circ}$ da CRP, em que se consagra o direito das crianças ao desenvolvimento integral, e do art. $73^{\circ}, \mathrm{n}^{0} 2$ da CRP, em que se recorta o desenvolvimento da personalidade como um dos fins da promoção da educação e cultura. Ora, esses dois preceitos conjugados com o art. $26^{\circ}$ da CRP mostram-nos que o sentido do direito ao desenvolvimento da personalidade não se reduz a um momento estático de proteção da integridade da pessoa; comporta também uma dimensão dinâmica que aponta para a “pessoa em devir" (CANOTILHO \& MOREIRA, 2007, p. 464) de modo a que a pessoa possa enriquecer a sua dignidade em termos de capacidade de prestação (CANOTILHO \& MOREIRA, 2007, p. 464) no plano pessoal, social e cultural. Relativamente à segunda dimensão - proteção da liberdade de exteriorização da personalidade -, esta abrange um conjunto de fatores, como a escolha do "modo de vida", a liberdade de profissão, passando pela liberdade de orientação sexual, a liberdade de ter ou não ter filhos, a "liberdade de estar só" (CANOTILHO \& MOREIRA, 2007, p. 464).

De acordo com Gomes Canotilho e Vital Moreira (2007, p. 464), apresentam-se como elementos nucleares do direito ao desenvolvimento da personalidade: 1) a 
possibilidade de "interiorização autónoma" da pessoa ou o direito a "auto-afirmação" em relação a si mesmo, contra quaisquer imposições heterônomas (de terceiros ou dos poderes públicos); 2) o direito a autoexposição na interação com os outros, o que terá especial relevo na exposição não autorizada do indivíduo nos espaços públicos; 3) o direito à criação ou aperfeiçoamento de pressupostos indispensáveis ao desenvolvimento da personalidade (ex. direito à educação e cultura, direito a condições indispensáveis à ressocialização, direito ao conhecimento da paternidade e maternidade biológica). $\mathrm{O}$ direito ao desenvolvimento da personalidade é o direito que permite a cada ser humano ser dotado de uma identidade. De fato, constituem direitos de personalidade, o direito à imagem, o direito à maneira de ser e de estar, o direito ao timbre de voz, entre outros. É esta identidade que permite distinguir os seres humanos entre si, tornando cada um desses seres humanos num sujeito único, que assim dotado de características genéticas e de personalidade próprias e únicas o permitem distinguir e identificar entre os seus semelhantes. Em suma, como nos ensina Jorge Miranda, a identidade pessoal é "aquilo que caracteriza cada pessoa enquanto unidade individualizada que se diferencia de todas as outras pessoas por uma determinada vivência pessoal" (MIRANDA \& MEDEIROS, 2010, p. 609). Em sentido amplo, o direito à identidade pessoal abrange o direito de cada pessoa a viver em concordância consigo própria, expressando livremente a sua consciência e modo de ser nas opções de vida que vai tomando. Assim, "o direito à identidade pessoal postula um princípio de verdade pessoal" (MIRANDA \& MEDEIROS, 2010, p. 609).

Este art. $26^{\circ}$ da CRP tutela, ainda, o direito à proteção legal contra quaisquer formas de discriminação, que se revela pela proeminente emissão de diplomas legislativos e instrumentos legais contra a discriminação, na medida em que se continua a verificar uma discrepância entre o princípio jurídico da igualdade e a realidade social, esta marcada por comportamentos, atos e situações discriminatórias.

O desenvolvimento da personalidade transporta uma dimensão de liberdade indispensável à auto conformação da identidade, da integridade e conduta do indivíduo, ou seja a liberdade enquanto "um poder de autodeterminação em virtude do qual o homem escolhe ele mesmo o seu comportamento pessoal. É um poder que o homem exerce sobre ele mesmo" (NETO, 2004, p. 117) através do qual expressa a sua vontade. Ora, se a vontade será "psicologicamente, o conjunto de fenómenos psíquicos. Eticamente, será uma atitude ou disposição moral para querer algo. Metafisicamente, por último, consistirá numa entidade à qual se atribui absoluta subsistência e se converte por isso em substrato de todos os fenómenos. A vontade não é concebível no estado puro e exprime-se no mundo dos factos e das estruturas sociais" (NETO, 2004, p. 295).

Efectivamente, só é possível a pessoa autoafirmar-se, tomar as suas decisões, firmar o seu verdadeiro "eu" se dotado de liberdade. Estamos no domínio da liberdade interna (a que se refere ao grau em que as ações de uma pessoa são guiadas pela sua 
própria vontade, para fazer o que se quer, ou poder satisfazer os desejos (NETO, 2004, p. 232). Pois, "a dimensão da (minha) liberdade" (NETO, 2004, p. 130) depende:

- de quantas possibilidades me são facultadas;

- de quão fácil ou difícil é realizar cada uma dessas possibilidades;

- de qual a importância que no meu plano de vida concedo a essas possibilidades;

- em que medida essas possibilidades são ou não desencadeadas por atos humanos deliberados;

- que valor dá não apenas o agente, mas o sentimento geral da sociedade em que vive, a cada uma das possibilidades (NETO, 2004, p. 234).

Cabe ao Direito fornecer o enquadramento legislativo por meio do qual todas as pessoas tenham igual acesso a condições que lhes permitam formar a sua personalidade, garantindo a existência de liberdade como conceito "eminentemente normativo moral (a liberdade como autonomia) e jurídico (a liberdade como liberdade fundamental ou civil)" (LOPES, 2007, p. 46). Garante-se a liberdade, garantindo-se uma esfera de não interferência dos outros na vida de cada um, facto pelo qual se geram deveres (negativos, de não interferência) para qualquer um, indivíduo ou colectividade, em relação a quem goza da liberdade (LOPES, 2007, p. 46).

Ora, se constitui incumbência do Estado, nos termos do art. $9^{\circ}$, alínea h) da CRP promover a igualdade entre homens e mulheres, assim se vinculando o Estado à observância e garantia dos direitos fundamentais, para que estes sejam dotados de efectividade prática há que ampliar a sua aplicabilidade a todos os sujeitos públicos ou privados, singulares ou coletivos, sem exceção (MIRANDA \& MEDEIROS, 2010, p. 221). Nesta senda, e na sequência do princípio geral de que todos os cidadãos são iguais perante a lei, a Constituição da República Portuguesa alarga inclusive o âmbito de proteção subjacente aos direitos fundamentais a todas as entidades privadas. Assim, o art. $18^{\circ}$, n. $^{\circ} 1$ da CRP é dotado de eficácia externa, pelo que o princípio da igualdade, como proibição de discriminação, pode impor-se às entidades privadas pelo que se reforça a ideia de uma igual posição em matéria de direitos e deveres. Estes direitos e deveres, em que se incluem os direitos fundamentais de que falamos, inclusive o direito à identidade e ao livre desenvolvimento da personalidade previsto no art. $26^{\circ}$ da CRP é diretamente aplicável a todas as pessoas, tendo como destinatários os próprios particulares nas relações entre si, circunstância em virtude da qual, eles prevalecem e se impõem no âmbito familiar (CANOTILHO \& MOREIRA, 2007, p. 387; MIRANDA \& MEDEIROS, 2010, p. 238).

Em suma, a dignidade da pessoa humana determina respeito pela liberdade da pessoa e pela sua autonomia, nomeadamente na definição e afirmação da sua identidade. 
De todo o exposto, verificamos que quer a Literatura quer o Direito como áreas do saber intrinsecamente ligadas à vida em sociedade e aos fenômenos sociais, refletem, espelham as questões de gênero. Assim, se por um lado encontramos o feminino retratado na literatura de forma abundante - a mulher constitui uma protagonista cuja riqueza de situações em que possa estar envolta constituem uma mais valia para a literatura. Por outro lado, a crença de que "a humanidade é masculina e o homem define a mulher não em si mas relativamente a ele; ela não é considerada um ser autónomo", considerando que "o corpo do homem tem um sentido em si, abstraindo do da mulher, ao passo que este parece destituído de significação se não se evoca o macho...Pensa-se o homem sem a mulher. Não ela sem o homem". Ela não é senão o que o homem decide que seja; assim é chamada "o sexo" para significar que ela se apresenta diante do macho como um ser sexuado: para ele, a fêmea é sexo, logo ela é-o absolutamente. A mulher determinase e diferencia-se em relação ao homem e não este em relação a ela; a fêmea é o não essencial perante o essencial. O homem é o ser, o Absoluto; ela é o Outro" (BEAUVOIR, 1987, p. 13). Nessa perspetiva, se "os dois sexos nunca partilharam o mundo em igualdade de condições" (BEAUVOIR, 1987, p. 17), "quando muito, consentia-se em conceder ao outro sexo "a igualdade dentro da diferença" (BEAUVOIR, 1987, p. 20), e se ainda hoje, embora a condição da mulher esteja a evoluir, esta tem um pesado handicap, na medida em que mesmo quando os direitos lhe são abstratamente reconhecidos, um longo hábito impede que encontrem nos costumes a sua expressão concreta (BEAUVOIR, 1987, p.17). Se "a liberdade natural, de que se fala no mundo moderno, se opõe à vida tradicional, à vida segundo regras convencionais aceites como se fossem necessárias e dadas" (LOPES, 2007, p. 46), é necessário fazer um esforço sério e global para alterar este estado de coisas.

Se a Literatura nos fornece imagens "reais" descritivas da vida em sociedade, como verificamos nos contos selecionados e analisados do Fio das Missangas, o Direito tem um importante papel a desempenhar, opondo-se muitas das vezes às formas de vida tradicional. Esta é uma tarefa complexa, na medida em que se pede às pessoas (inclusive às mulheres) que deixem de considerar as coisas como elas lhes são apresentadas e se coloquem como espectadores das instituições sociais existentes, pedindo-lhes que imaginem "uma situação em que se coloque em suspenso a tradição pura e simples" (LOPES, 2007, p. 46).

E como afirma José Reinaldo Lopes (2007, p. 46) esse exercício é uma chamada ao pensamento, à consciência ou à reflexão sobre as formas de vida possíveis e desejáveis. Esse apelo à liberdade é crítico porque do facto de se reconhecer que a cooperação social é necessária para a sobrevivência da espécie não deriva a aceitação de todas as convenções sociais, qualquer que elas sejam. 
O que se pede ao ser humano é que este seja capaz de escolher alternativas, de desenvolver a sua capacidade de escolher, de tomar o leme da sua vida individual como bem entender, sem receio de sofrer quaisquer tipos de constrangimentos quer de outras pessoas quer do Estado. O Poder Legislativo tem assim o importante papel de incrementar a eliminação desses constrangimentos, de consagrar a liberdade como um valor "liberdade nesses termos significa liberdade moral e liberdade civil em primeiro lugar, ou seja, uma forma de organizar a cooperação de modo a que alguns não vivam em função de outros" (LOPES, 2007, p. 46).

Para esse efeito, como vimos, quer o direito internacional quer o ordenamento jurídico português fornecem mediante a consagração de direitos fundamentais dotados de carácter constitucional, do princípio da dignidade da pessoa humana (art. $2^{\circ}$ da CRP), do princípio da igualdade (art. $13^{\circ}$ da CRP) e dos direitos fundamentais, em particular do direito ao desenvolvimento da personalidade, dos direitos de personalidade consagrados, constitucionalmente, no art. $26^{\circ}$ instrumentos que permitem a proteção e manutenção do princípio estruturante da dignidade do ser humano. A proteção dos direitos de personalidade assume particular importância em face dos contos do Fio das Missangas na medida em que, como vimos, no âmbito deste direito se insere a liberdade de ação de acordo com o projeto de vida de cada pessoa, o direito à formação livre da personalidade sem imposições de qualquer tipo por parte de terceiros, pessoas ou sociedade ou meio em que aquele indivíduo está inserido. Ora, a escolha do modo de vida, ou a existência de liberdade de exteriorização da personalidade, portanto a afirmação da identidade, são aspectos a que não assistimos nas personagens descritas por Mia Couto.

Olhamos para Gilda, Flornela e Evelina do conto "As três irmãs" e verificamos que o pai semeou nelas um destino "o destino que Rosaldo semeara nelas: o serem filhas exclusivas e definitivas", a tal ponto que "as irmãs nem deram conta do seu crescer" transformando-se em seres não dotados de identidade própria, nas palavras do narrador "olhemos as meninas, uma por uma, espreitemos o seu silencioso e adiado ser". A estas três "criaturas" não foi permitido o exercício de liberdade suficiente para determinarem o seu próprio ser, o seu próprio destino. Vivem não para si próprias e em função dos seus objetivos, mas em função dos objetivos do pai e de acordo com o modo de vida deste.

Também no "O cesto" a protagonista da história reconhece "já não recebo enxovalho, ordem de calar, de abafar o riso"; à jovem de "A saia amarrotada" foram-lhe embutidos valores relacionados com as funções domésticas que esta deveria desempenhar, assim como vergonha sobre o próprio corpo e sobre a sua identidade como mulher, negando a sua sexualidade, como se descreve no texto, nasceu para "cozinha, pano e pranto", ensinaram-lhe "tanta vergonha em sentir prazer" que acabou "sentindo prazer em ter vergonha", estando "habituada a não ter motivo", ou seja, não tinha objetivos de vida, não tinha liberdade para poder escolher o seu rumo de vida, expressar a sua 
maneira de ser, comparando inclusive as ordens do pai à voz e aos mandamentos de Deus, como se de uma religião se tratasse e não houvesse a mínima possibilidade de não agir como lhe era determinado ou ordenado pelo pai. Repare-se que esta jovem, quando lhe é dada ordem para queimar o vestido e esta desobedece reconhece ser guiada pelo diabo "Não cumpri. Guiaram-me os mandos do diabo e, numa cova, ocultei esse enfeitiçado enfeite". A conduta desta jovem é rodeada de um misticismo que a leva a associar os acontecimentos da sua vida a obra de Deus ou do diabo, não tendo consciência de que se poderia tratar de um direito.

À mulher protagonista de "Meia culpa, meia própria culpa" considerando-se "menor de existência" já só desejava aceder a seu pensamento "saio pelo pé de meu pensamento" e aceder às suas recordações "depois de matar o Seis reganhei acesso a minhas lembranças", idêntica situação era vivida pela figura feminina que nos narra "Os olhos dos mortos", declarando que "eu estava no pranto como quem sustenta sua própria raiz. Chorando sem direito a soluço; rindo sem acesso a gargalhada", "sem pertença nem presença".

A todas essas mulheres era negada a liberdade de poder decidir suas vidas, comandar seus destinos, sendo a sua existência determinada pela vontade alheia. A estas mulheres são negados os direitos fundamentais de personalidade, o rir, o chorar, o decidir constituir ou não família, o direito à imagem (é-lhes vedado o uso de vestidos e saias, peças de roupa femininas) o direito a serem mulheres, a identificarem-se como mulheres.

No conto "Na tal noite", para além do já exposto em termos de supressão do direito à identidade e à personalidade daquela mulher, ainda se verifica a não observância do princípio da igualdade entre cônjuges, não dispondo a mulher da mesma capacidade de decisão e determinação da vida familiar, descrevendo-se o marido como "dono".

Ciente da realidade que constitui a existência de situações como as descritas, o Direito alarga o seu âmbito de aplicação às relações entre privados inclusive às relações familiares, tornando diretamente aplicáveis a todas as pessoas quer singulares quer coletivas quer públicas quer privadas a vinculação que decorre da consagração dos direitos fundamentais (o que no ordenamento jurídico português ocorre por força do art. $18^{\circ}$ da CRP).

O objetivo final será condenar à extinção estas formas de "não-existência", de "esquecimento de seres humanos", de proibir e penalizar o tratamento desses humanos como objetos adstritos à satisfação de necessidades alheias e ao cumprimento de determinada função, e que depois de usados e de esgotado o seu valor de uso são simplesmente desprezados, abandonados, evitando o tratamento da mulher como uma saia velha e amarrotada, como um cesto de comida ou um fio de missangas. 


\section{CONCLUSÃO}

Terminamos com um excerto também da autoria de Mia Couto, da obra $A$ varanda dos Frangipani:

"Nós, mulheres, estamos sempre sob a sombra da lâmina: impedidas de viver enquanto novas; acusadas de não morrer quando já velhas" (MIA COUTO, 2003, p. 82)

O Fio das Missangas transmite-nos essa ideia, a mulher que é impedida de viver. Esse sentimento de que à mulher não é permitida a vida. $\mathrm{O}$ usufruto da vida é uma questão educacional, social e cultural, trata-se de saberes, modos de vida e tradições que passam de geração em geração, e em que muitas vezes, de fato, a mulher se vê subjugada mas em simultâneo sem saber ou sem dispor de meios ou vontade para sair dessa situação.

Sempre que esses saberes, modos de vida e tradições se revelem contrários ao princípio da dignidade da pessoa humana, devem ser denunciados para posteriormente serem contrariados e desincentivados. A literatura constitui, nesse aspeto, um importante meio de obtenção de informação.

E, se como afirmou Percy Bysshe Shelley, "Os poetas são os legisladores não reconhecidos do mundo" (citado por CUNHA, 2007), ou atualmente Raquel Freitas que "todo o poeta deve ser legislador do mundo", ou ainda Germano Schwartz que propõe uma inversão desses termos afirmando que "todo o legislador e decisor judicial seria poeta do mundo" (citado por CUNHA, 2007). O que é determinante é a interligação destas duas artes - Direito e Literatura - com vista à eliminação das eventuais situações lesivas de direitos fundamentais que a sociedade ainda perpetue.

Concluímos como começamos, com o Fio das Missangas tal como descrito pelo próprio autor:

"A missanga, todas a vêem.

Ninguém nota o fio que,

Em colar vistoso, vai compondo as missangas.

Também assim é a voz do poeta:

Um fio de silêncio costurando o tempo"

Tomando a liberdade de pedir que à missanga, a mulher todos a vejam, como mulher, como ser humano. Que o fio no qual se compõem as missangas seja um fio "Direito", em que valores como a igualdade, a liberdade, a identidade, a autonomia de cada ser permitam construir uma sociedade ou seja um belíssimo colar. "Porque o poeta é um legislador do mundo..." (FREITAS, 2002, p.22), que a voz do poeta nunca se cale permitindo denunciar ao Direito as virtudes e defeitos da matéria-prima sobre que este assenta. Para que o tempo se costure de modo igual para todos e em que todos possam ser protagonistas. 


\section{REFERÊNCIAS}

ABRANTES, José João. A vinculação das entidades privadas aos direitos fundamentais. Lisboa: AAFDL, 1990.

AMÂNCIO, Lígia. Masculino e Feminino - a construção social da diferença. Porto: Centro de Estudos Sociais, Edições Afrontamento, 1994.

BEAUVOIR, Simone. O Segundo Sexo - I - os factos e os mitos, 4.ed. Venda Nova: Bertrand Editora, 1987.

CANOTILHO, J. J. Gomes \& MOREIRA, Vital. Constituição da República Portuguesa Anotada, v. I, 4.ed. revista. Coimbra: Coimbra Editora, 2007.

CANOTILHO, J.J. Gomes. Direito Constitucional, 6.ed. Coimbra: Almedina, 1995.

COUTO, Mia. A Varanda do Frangipani, 7.ed. Lisboa: Caminho, 2003.

COUTO, Mia. O Fio das Missangas, 4.ed. Lisboa: Caminho, 2004.

CUNHA, Paulo Ferreira da. "Direito e Literatura - introdução a um diálogo". In: Notandum, Ano X, n. 14, 2007.

FREITAS, Raquel Barradas. Direito, Linguagem e literatura: reflexões sobre o sentido e alcance das inter-relações - breve estudo sobre dimensões de criatividade em Direito, Working Paper 6/02 da Faculdade de Direito da Universidade Nova de Lisboa. Lisboa: FDUNL, 2002.

LOPES, José Reinaldo de Lima. "Liberdade e direitos sexuais - o problema a partir da moral moderna". In: ROGER RAUPP RIOS (Org.) e outros, Em defesa dos direitos sexuais. Porto Alegre: Livraria do Advogado Editora, 2007.

MIRANDA, Jorge \& MEDEIROS, Rui. Constituição da República Portuguesa Anotada, tomo I, 2.ed. Coimbra: Wolters Kluwer Portugal/ Coimbra Editora, 2010.

NETO, Luísa. $O$ direito fundamental à disposição sobre o próprio corpo (a relevância da vontade na configuração do seu regime). Coimbra: Coimbra Editora, 2004.

\section{Recursos eletrónicos:}

ALVES, Tatiana (2009). O feminino em MIA COUTO. Disponível em http://www.cronopios.com.br/ site/ensaios.asp?id =4118, consultado em 12/10/2010.

QUELHAS, Iza (2001). Identidade e eventos - uma leitura de "Mulher de Mim", de MIA COUTO. Disponível em http://webcache.googleusercontent.com/search?q=cache:JedV0J_4GwsJ:alfarrabio. diuminho.pt/vercial/zips/quelhas01.RTJ $+\mathrm{a}+$ mulher + na + literatura + de + mia $+\operatorname{couto\& cd}=4 \& h \mathrm{l}=\mathrm{p}$ t_PT\&cT $=$ clnk\&gl=pt, consultado em 12/10/2010.

SILVA, Joana Maria Madeira de Aguiar (2008). Para uma teoria hermenêutica de justiça. Repercussões jusliterárias no eixo problemático das fontes e da interpretação jurídicas.Disponível em http://www.estig.ipbeja.pt/ ac_direito/TeseJASilva.pdf, consultado em 12/10/2010. 